ROCZNIKI TEOLOGICZNE

Tom LXVII, zeszyt $11-2020$

DOI: https://doi.org/10.18290/rt206711-8

REV. ADAM JASZCZ

\title{
THEOLOGICAL AND CANONICAL ASPECTS OF BAPTISMAL MYSTAGOGY TO PERSONS BELOW 14 YEARS OF AGE
}

\begin{abstract}
The aim of this article is to present the theological grounds for administering baptism to children and minors under 14 years of age and the canonical status of it, as well as the pastoral and administrative implications arising therefrom. The consequence of baptism is the sanctifying and justifying incorporation into the People of God's New Covenant. It cannot be revoked, and its sacramental character is irremovable. Man, reborn with baptismal water, is freed from Adam's guilt and endowed with the power to overcome evil. The author refers to the thesis that the baptism of children violated their religious freedom. The article states that there is no such thing as "pure human freedom," independent of any influence. Parents care for the wellbeing of their children and things necessary for life. This also applies to religious life. Not caring about this aspect would in fact be a wish of evil by depriving a person of a good. The author describes the consequences arising from the sacrament of baptism, through which a legal node is created in a particular Church sui iuris.
\end{abstract}

Keywords: baptism; child; minor; Church; religious freedom; law.

In the first centuries of Christianity Church Fathers were already interested in the baptism of children who could not confess their faith. The Church began to administer this sacrament at Pentecost (cf. Acts 2:38), imposing the condition of conversion of heart and confession of faith in Jesus Christ (cf. Acts $2: 41 ; 8: 12-13 ; 16: 15)$. In the Book of Acts we read that entire families were baptized (cf. Acts 16:15; 16:33; 1 Cor 1:16), which means that children received this sacrament as well. When it comes to documenting this practice, there is historical evidence dating back to the second century. In the middle

ADAM JASzCZ, PhD, Institute of Canon Law, Faculty of Law, Canon Law and Administration, John Paul II Catholic University of Lublin; address for correspondence: ul. Spokojna 1, 20-400 Lublin, Poland; e-mail: ajaszcz@op.pl; ORCID: https://orcid.org/0000-0003-2282-1523. 
of the third century, St. Cyprian, bishop of Carthage, in a letter addressed to Bishop Fidus, strongly opposed the opinion that the baptism of a child should be postponed until the eighth day after its birth. This practice was to be a reference to the Jewish custom of circumcision on the eighth day after birth. The synod of African bishops of AD 251 argued for the necessity of baptizing children immediately after birth. The core of this opinion was the belief that baptism was necessary for salvation. ${ }^{1}$

A person who is under the age of eighteen is considered a minor under canon law (persona minor). If they are under seven, they are called a child (infans) and considered unable to conduct themselves. It is presumed that after the age of seven, a person is able to be governed by their mind. This is a simple presumption, allowing for contrary evidence. In exercising their rights, a minor depends on the authority of parents and guardians, which is reflected in canonical norms. ${ }^{2}$

The sacrament of baptism has always been considered the foundation of Christian life as "the gateway to life in the Spirit" and "the door that opens the introduction to other sacraments." ${ }^{3}$ It is necessary for salvation for those to whom the Gospel was preached and who had the opportunity to ask for this sacrament. The document of the International Theological Commission states:

God's grace reaches all people and his providence embraces all. The Second Vatican Council teaches that God does not deny "the assistance necessary for salvation" to those who, without any fault of their own, have not yet arrived at an explicit knowledge of God, but who, with the help of grace, "strive to lead a good life." God enlightens all people "that they may at length have life" (cf. $L G 16$ ). Again, it teaches that grace is "active invisibly" in the hearts of all people of good will (GS 22). These words apply directly to those above the age of reason, who are making responsible decisions, but it is difficult to deny their applicability also to those below the age of reason. The following words, in particular, seem truly universal in their scope. "For since Christ died for all, and since all are in fact called to one and the same destiny, which is divine [cumque vocatio hominis ultima revera una sit, scilicet divina], we must hold that the Holy Spirit offers to all the possibility of being made partners, in a way known to God, in the paschal mystery" (GS 22).

\footnotetext{
${ }^{1}$ Cf. Tomasz BiszKo, "Sakrament chrztu św. w świetle Katechizmu Kościoła Katolickiego," Legnickie Studia Teologiczno-Historyczne 14 (2009): 254.

${ }^{2}$ Cf. Tadeusz Pawluk, Prawo kanoniczne wedlug Kodeksu Jana Pawta II, vol. 1, Zagadnienia wstępne i normy ogólne (Olsztyn: Warmińskie Wydawnictwo Diecezjalne, 2015), 254.

${ }^{3}$ Catechism of the Catholic Church (Chicago: Loyola University Press, 1994), no. 1213.
} 
This profound sentence of Vatican II takes us into the heart of the loving purpose of the blessed Trinity and stresses that God's purpose exceeds our understanding. ${ }^{4}$

The fundamental elements of Catholic theology of baptism were presented in various documents of the Second Vatican Council. They are in direct relation with canonical norms. They influenced the writing of both the new Rite of Baptism for Children, ${ }^{5}$ promulgated on May 15, 1969, and the 1983 Code of Canon Law. ${ }^{6}$

\section{THE CHURCH'S PRACTICE REGARDING ADMINISTERING BAPTISM TO CHILDREN}

The Latin word baptismus, baptisma is derived from the Greek $\beta \alpha \pi \tau i \zeta \omega$, and means the visible act of immersion, bathing, drowning, or submerging in water. ${ }^{7}$ In the oldest accounts (Sumer, Egypt, India), water was perceived as the primeval material of being and the source of life. This idea is also present in the Book of Genesis, according to which the world emerged out of water through the Lord's creative words: "In the beginning, God created the heaven and the earth.... Darkness was upon the face of the deep. And the Spirit of God moved upon the face of the waters" (Gen. 1:1-2). ${ }^{8}$ Therefore, baptism should be understood as a liturgical act of the Church, available to human senses and perception, through which a believer is accepted into the Christian community of faith, and which is a sign and means of community with God and His people. ${ }^{9}$

Returning to the biblical sources, it should be noted that the baptism given by John the Baptist in the River Jordan was a breakthrough in comparison with earlier religious practices: it was performed by another person. Therefore, it was not a self-washing, as in the case of Jewish ritual washing. The baptism of Jesus became something much more important from the point

\footnotetext{
${ }^{4}$ International Theological Commission, The Hope of Salvation for Infants Who Die without Being Baptised, 81a (also available on vatican.va).

${ }^{5}$ Rite of Baptism for Children (Washington, D.C.: United States Catholic Conference, 1969).

${ }^{6}$ Codex Iuris Canonici auctoritate Ioannis Pauli PP. II promulgatus, January 25, 1983, AAS 75 (1983), pars II, 1-317, cc. 849-878.

${ }^{7}$ Cf. Bogusław Nadolski, Leksykon liturgii (Poznań: Pallottinum, 2006), 239.

${ }^{8}$ Cf. Czesław S. BARTniK, Dogmatyka katolicka (Lublin: Wydawnictwo KUL, 2003), 2:668.

${ }^{9}$ Cf. Gerhard L. MüLler, Dogmatyka katolicka (Kraków: WAM, 2015), 670.
} 
of view of salvation history because it meant the proclamation of His royalty and messianism, as well as the epiphany of His sonship. The sources of this baptism should be sought in the Paschal Mystery, in the death and resurrection of Christ, and in the outpouring of the Holy Spirit for the remission of sins by the Resurrected Kyrios. The command to administer baptism given to the apostles is therefore a visible manifestation of the immersion of humans in the death and resurrection of Christ. ${ }^{10}$

The Second Vatican Council states in its dogmatic constitution:

In the human nature united to Himself the Son of God, by overcoming death through His own death and resurrection, redeemed man and re-molded him into a new creation (cf. Gal. 6:15, 2 Cor. 5:17). By communicating with His Spirit, Christ made His brothers, called together from all nations, mystically the components of His own Body. In that Body, the life of Christ is poured into the believers who, through the sacraments, are united in a hidden and real way to Christ who suffered and was glorified. Through Baptism, we are formed in the likeness of Christ: "For in one Spirit we were all baptized into one body" (1 Cor. 12:13). In this sacred rite a oneness with Christ's death and resurrection is both symbolized and brought about: "For we were buried with Him by means of Baptism into death"; and if "we have been united with Him in the likeness of His death, we shall be so in the likeness of His resurrection also" (Rom. 6:4-5). ${ }^{11}$

Baptism is the gateway to the life and Kingdom of God. It is also the first sacrament of the new law; Christ brought it to all people, so that they could have eternal life. Then, it was entrusted to the Church along with the command given to the Apostles: "Go, therefore, make disciples of all nations; baptise them in the name of the Father and of the Son and of the Holy Spirit" (Matt. 28:19).

His lost friendship with God is renewed and strengthened, and the baptised is included in the filial relationship of the Son and Father in the Holy Spirit. ${ }^{12}$ There are specific consequences resulting from this, because "the faithful are by baptism made one body with Christ, and are constituted among the People of God; they are in their own way made sharers in the priestly, prophetical, and kingly functions of Christ; and they carry out for

\footnotetext{
${ }^{10}$ Cf. NADOLSKI, Leksykon liturgii, 240.

11 Vatican II, Dogmatic Constitution on the Church Lumen gentium, November 21, 1964 : AAS 57 (1965), 5-75, no. 7 (English version available on www.vatican.va).

${ }^{12}$ Cf. MülLer, Dogmatyka katolicka, 670.
} 
their own part the mission of the whole Christian people in the Church and in the world." 13

Referring to God's mercy and Jesus' love for children, the Catechism of the Catholic Church hopes that there is a way of salvation for children who died without baptism and therefore encourages the parents of Catholic children who died prematurely, especially those who baptized them or they had the will to do so, to pray. ${ }^{14}$

The Church, having received the mission of preaching the Gospel and administering baptism, have been baptising not only adults but also infants. Children should not be denied baptism, because they are baptised in the faith of this very Church, which is publicly professed by parents, sponsors, and other liturgical participants. It is these people who become representatives of the local Church, but also of the entire community of saints and believers. In this way, the Mothering Church gives birth to each and every one. Children and infants are defined in Rite of Baptism for Children as those who can neither possess nor profess their faith because they have not yet reached the age of discretion. ${ }^{15}$

Baptism of children and infants is a practice which can be proven to have existed since the second century. The Church Fathers considered it an apostolic tradition. There is a necessary connection between faith and baptism here because children are baptised due to the faith of the Church, which is represented by their parents and sponsors. They are also the ones with the obligation to provide children with basic religious education. Exculpation is given not by subjective acts of faith, conversion, and obedience, but by the primacy of grace that surpasses all personal acts of faith. Small children who have not yet committed any personal sins are also baptised in accordance with the Church's rite for the remission of sins. This is because they were under the governance of Adam's sin before they even stood for or against the faith. In the moment of baptism, they receive the Church's objective faith as a grace. When they grow up, they should freely accept and develop this faith in their specific life choices. ${ }^{16}$ In the case of children receiving baptism as infants, as the years go by and as they grow in the community, a multilevel and diverse baptismal catechumenate takes place, which consists of multilateral mental, spiritual, moral and experience development.

\footnotetext{
${ }^{13}$ VATICAN II, Lumen gentium, no. 31.

${ }^{14}$ Cf. Catechism of the Catholic Church, no. 1261.

${ }^{15} \mathrm{Cf}$. Rite of Baptism for Children, nos. 1-2.

${ }^{16}$ Cf. MüLLER, Dogmatyka katolicka, 677.
} 
The doctrinal foundations of baptism for children were deepened by Saint Augustine. Bishop of Numidia Boniface asked Augustine how someone could say during the baptism of infants that they have faith if they are unable to profess it. Augustine stated that they have faith because of the sacrament of faith they receive. It is the sacrament of faith that makes a child still unable to believe a believer. ${ }^{17}$

Children or infants are people who cannot personally confess their faith because they have not yet reached the age of discretion. Parents who ask for baptism on behalf of a child become a guarantee that they will be brought up in the Catholic faith. Small children are not yet able to confess their faith by their own act, which is why others do it instead. The church also imposes a certain limitation in this regard: apart from the risk of death, it does not allow for the baptism of a child without parental consent and without the guarantee that the child will be brought up in the Catholic faith. ${ }^{18}$

For an infant to be baptized licitly, the parents or at least one of them, or the person who legitimately takes their place, must consent; there must be a founded hope that the infant will be brought up in the Catholic religion; if such hope is altogether lacking, the baptism is to be delayed according to the prescripts of particular law after the parents have been advised about the reason. An infant of Catholic parents or even of non-Catholic parents can be baptized licitly in danger of death even against the will of the parents (c. 868 $\S \S 1-2)$. In addition, the Council's Declaration on Religious Freedom states that every family, as a society in its own original right, has the right to freely live its own domestic religious life under the guidance of parents. Parents, moreover, have the right to determine, in accordance with their own religious beliefs, the kind of religious education that their children are to receive. ${ }^{19}$

The above postulates may be difficult to fulfil in mixed marriages. The decision to enter into a mixed marriage should be preceded by special consideration so that it is taken by both parties in freedom and in a mature way. This is required by the legislator in canon 1125. Canonical solutions regarding mixed marriages are in line with the spirit of ecumenical respect and

${ }^{17}$ Cf. BiszKo, "Sakrament chrztu," 55.

${ }^{18}$ Cf. María Blanco, "Coment. sub can. 868," in Comentario Exegético al Código de Derecho Canónico, ed. Ángel Marzoa, Jorge Miras, and Rafael Rodríguez-Ocaña (Pamplona: EUNSA, 1996), 3:488-89.

${ }_{19}$ Vatican II, Declaration on Religious Freedom Dignitatis humanae, December 7, 1965: $A A S 58$ (1966), 929-46, no. 5 (English version available on www.vatican.va). 
openness to other religions and creeds, i.e., they guarantee the protection of the fundamental right of freedom of conscience and religion. However, you cannot raise children in the generally understood "Christian religion." They must identify with a specific community, which will be reflected in the baptism in the Catholic Church. The Catholic upbringing of a child in mixed marriages may face various difficulties. Only the Catholic parent undertakes to bring up the child in their faith, while the other parent only accepts that. Their declaration does not mean that they will help in fulfilling this obligation. Also, in the case of a Catholic parent, their commitment depends largely on goodwill. The words of commitment that they "will do everything in his or her power to realise the duty" draw attention to this. ${ }^{20}$

\section{BAPTISM OF CHILDREN AND RELIGIOUS FREEDOM}

An accusation is sometimes made that baptising children is a breach of their religious freedom. This way of thinking should in its very roots be considered erroneous, because there is no human freedom so pure that it is immune from being influenced in any way. Given the natural order of things, parents care for what is essential for life and what fosters the well-being of their children. A so-called neutral attitude on the part of the family with regard to the child's religious life would in fact be a negative choice that would deprive the child of an essential good. ${ }^{21}$ Canon 849 defines the "essential good" resulting from the sacrament of baptism: "Baptism, the gateway to the sacraments and necessary for salvation by actual reception or at least by desire.... Through baptism, men and women are freed from sin, are reborn as children of God, and, configured to Christ by an indelible character, are incorporated into the Church."

In addition, the invocation of the "freedom" argument in the context of delaying baptism in the case of children strikes at those who invoke such an argument. For baptism is a means wanted by God, initiating a supernatural life in man, opening him to life in grace. A human person has the unques-

\footnotetext{
${ }^{20}$ Cf. Rafał KAMIŃSKI, "Wychowanie dzieci w małżeństwach mieszanych,” in Chrzest i matżeństwo: harmonizacja ustawodawstwa, ed. Henryk Stawniak and Rafał Kamiński, 141-42 (Warsaw: Scriptum, 2018).

${ }^{21}$ For more, see CONGREgation FOR THE Doctrine OF THE FAith, Instruction on Infant Baptism Pastoralis actio, October 20, 1980: AAS 72 (1980): 1137-156.
} 
tioned right, of which no one can deprive them, to receive the gift from God. Anyone who would deny the need for baptism of a newborn in the name of a misunderstood freedom would claim the right to administer others' freedom in making decisions. Thus, they would deprive the child of the right to receive a gift given by God. It is an attempt on the child's freedom, just like it would be, in natural order, to act against the birth and growth of a child, evoking the argument that the child had not previously agreed to their birth. ${ }^{22}$ Tadeusz Pawluk notes that, just as the state, through appropriate laws, ensures that the child, regardless of their will, has the right to possess worldly goods, canon law provides them with spiritual goods. ${ }^{23}$

Parents who ask for the baptism of their child usually are guided by religious motives. Such a request is also made by people connected by a civil contract, or parents who want to keep the tradition or are afraid of the unfavourable opinion of their community. The instruction of the Congregation for the Doctrine of the Faith on the baptism of children Pastoralis actio of October 20, 1980, recalls two principles that should be borne in mind when deciding to grant baptism: the need for baptism for salvation and the need to ensure education in faith and Christian life. With respect to this second principle, the instruction imposes an obligation to provide a warranty (assurances) about the Catholic upbringing of a child, which is usually given by parents or relatives, although they may be supplemented in various ways within the Christian community. Ensuring the Catholic upbringing of a child does not have to be based solely on the religious life of parents or on their assurance. Sufficient warranty may be the religious attitude of other relatives, e.g., godparents, grandparents or other relatives, however, with the proviso that these people have the opportunity to influence the religious upbringing of the child on a daily basis and parents do not object. Thus, when parents ask for baptism only occasionally practicing their faith or living without a religious wedding and unable to enter into a sacramental marriage, or even non-Christian parents, the pastor should hear them and carefully consider the arguments. ${ }^{24}$

Postponing baptism is intended to deepen the parents' faith and make them aware of their obligations arising from the sacrament of baptism. This

\footnotetext{
${ }^{22}$ Cf. Tomás RinCÓN-PÉREZ, "Disciplina canónica del Culto Divino," in Manual de derecho canónico, obra a cargo del Instituto Martin de Azpilcueta (Pamplona: EUNSA, 1988), 429.

${ }^{23}$ Cf. Tadeusz Pawluk, Prawo kanoniczne wedtug Kodeksu Jana Pawła II, vol. 2, Lud Boży jego nauczanie i uświęcanie (Olsztyn: Warmińskie Wydawnictwo Diecezjalne, 2009), 330-31.

${ }^{24}$ Cf. Congregation for the Doctrine of the Faith, Pastoralis actio, no. 28.
} 
may give hope in the future for a Catholic upbringing of a child. Postponing the baptism referred to in canon $868 \S 1$, should take place in accordance with the provisions of particular law.

Catholic parents are committed to ensuring that their children receive baptism within the first weeks, as soon as possible after birth. The legislator recommends going to one's own parish priest even before the birth of a child, to ask for the sacrament and to prepare for it properly. In danger of death, a child must be baptised immediately (Can. 867).

\section{CANONICAL ASPECTS}

Baptism is granted according to the rite prescribed in the approved liturgical books. Only in the event of urgent necessity should only be used what is required for the validity of the sacrament (c. 850). In danger of death, if time is urgent, you should use the abbreviated baptismal rite, which involves pouring water on the baby's head and saying the usual formula: "I baptize you in the name of the Father, Son and Holy Spirit."

From the dogmatic point of view, the specific sacramental sign of baptism consists of matter and form. Further matter is natural, running water (it does not have to be holy), and proximate matter-washing with this water. Washing can be done by pouring water, immersion in water or sprinkling with water (currently not allowed, unless no other option is available). ${ }^{25}$

Code standards determine the manner of administering the sacrament: by immersion or by pouring, subject to the provisions issued by the episcopal conference. True baptism can be performed validly only by a washing of real water (per lavacrum aque verae), while using the proper form of words (cum debita verborum forma) (cc. 854, 849). This provision sanctions Christ's concern and command regarding the necessity of spiritual rebirth as the first and necessary condition of eternal salvation (cf. John $3: 3$ ). ${ }^{26}$

The ordinary ministers of baptism are bishop, presbyter, and deacon. Parish priests entrusted with pastoral care in a given area should be considered as special associates of the bishop. They are the ones who are first and foremost

\footnotetext{
${ }^{25}$ Cf. BARTNIK, Dogmatyka katolicka, 669.

${ }^{26}$ Cf. Józef KRZYwDA, "Chrzest," in Komentarz do Kodeksu prawa kanonicznego, vol. 3/2, Księga IV. Uświęcające zadanie Kościoła, ed. Wojciech Góralski et al. (Poznań: Pallottinum, 2011), 35-36.
} 
legally obliged to administer this sacrament. Other presbyters and deacons, as assistants of the bishop and the parish priest, prepare for baptism and also administer the sacrament if the bishop or parish priest calls them to do it or gives their consent. In the absence of the ordinary minister, a catechist or other person appointed by the local ordinary administers baptism licitly. If necessary, any person with the right intention can baptise a child. The special duty of pastors, especially parish priests, is to instruct the faithful about proper administration of baptism (cc. 861-863). ${ }^{27}$ The ability to administer baptism by an extraordinary minister is connected with the special duty of pastors to pay attention to the preparation of health care professionals, as well as medical school pupils and students in this matter. This responsibility lies with the catechists and chaplains of health care facilities. ${ }^{28}$

Baptism can be administered on any day, but it is recommended that it is administered on Sunday or, if possible, at the Easter Vigil. The proper place to administer the sacrament, apart from a case of necessity, is the church or chapel. Baptism is a sacrament that includes into the People of God, of which the parish is a part; therefore, the most appropriate place is the parish church of the person receiving the sacrament. Baptism should not be administered in hospitals unless the diocesan bishop decides otherwise. This practice is also justified by necessity or some other pastoral reason (cc. 856-860). ${ }^{29}$

It is the right and authority of parents to name their child. Pastors preparing for baptism should encourage the faithful to give their children names in a prudent manner. Canon 855 obliges parents not to give a name foreign to Christian sensibility. Care must be taken that the names given were not contrary to faith. ${ }^{30}$

Parents who ask for the baptism of a child, as well as those who perform the function of sponsors, should be properly instructed about the meaning of

${ }^{27}$ Cf. RinCÓN-PÉREZ, "Disciplina canonica," 431; Krzysztof MikOŁAJCZUK, Realizacja zasady jedności sakramentów wtajemniczenia chrześcijańskiego w prawodawstwie Kościoła Katolickiego (Kielce: Jedność, 2006), 214-15.

${ }^{28}$ Cf. Leszek ADAmowicz, Wprowadzenie do prawa o sakramentach świętych: wedtug Kodeksu Prawa Kanonicznego oraz kodeksu Kanonów Kościołów Wschodnich (Lublin: Polihymnia, 1999), 63.

${ }^{29}$ Cf. RINCÓN-PÉREZ, "Disciplina canonica," 432.

${ }^{30}$ The 1917 Code of Canon Law obliged parents to give their children Christian names. If the name given earlier did not meet this criterion, the parish priest was legally obliged to give the name of one of the saints and write both names in the certificate; see Codex Iuris Canonici auctoritate Pii X Pontificis Maximi iussu digestus Benedicti. Papae XV auctoritate promulgatus, May 27, 1917: AAS 9 (1917), pars. II, 1-593, c. 761. 
the sacrament and the obligations associated with it, which also applies to the structure of the liturgical celebration (c. $851 \S 2) .{ }^{31}$ Canon 1366 provides for a canonical sanction for parents who would baptize their children in any a-Catholic community.

According to the rule in force since the Council of Trent one godmother or godfather or two godparents should be established (c. 873). A greater number of godparents are not permitted by canon law.

A person who wants to take on the tasks of a sponsor should have completed their sixteenth year of age, unless the diocesan bishop decides otherwise, or the pastor or minister grants an exception for a just cause. The sponsor should be a Catholic who has been confirmed and has already received the sacrament of the Eucharist, who leads a life of faith, and who is not be bound by any canonical penalty legitimately imposed or declared. Moreover, they cannot be the father or mother of the person to be baptised (c. $874 \S \S 1-2$ ). There is a possibility of allowing a Christian belonging to the Eastern NonCatholic Church to be a sponsor, but always along with a Catholic sponsor. Ecumenical reasons support this. ${ }^{32}$

The parish priest of the place where the baptism is administered must carefully and without any delay record the names of the baptised in the baptismal register. The following should be noted: names of the baptised, making mention of the minister, parents, sponsors, and any witnesses, as well as the place and date of baptism. The date and place of birth are also stated (c. $877 \S 1$ ).

A child in danger of death can be properly baptized, even against the wishes of parents, even if they are not Catholic (c. 868 §). Such a decision results from putting the child's good, i.e. his or her salvation, above the natural rights of parents. In practice, this power should be used very carefully.

A child that was left by the parents or found should be baptized if it cannot be determined after a thorough investigation that he or she was baptized (c. 870). Miscarried children, if alive and if possible, should be baptized (c. 871). This is a consequence of the truth that a conceived child has an immortal soul. The 1917 Code contained detailed provisions on this matter.

31 Cf. RINCÓN-PÉREZ, "Disciplina canonica," 169; for more, see Tadeusz SYCZEWSKI, “Sakrament Chrztu Świętego," Studia Teologiczne-Białystok-Drohiczyn-Lomża 15 (1997): 155-76.

${ }^{32}$ Cf. Pontifical Council for Promoting Christian Unity, Directoire pour l'application des principes et des normes sur l'oecuménisme, March 25, 1993: AAS 85 (1993), 1039-119, no. 98b; for more, see Wojciech GóRALSKI, "Wymiar ekumeniczny Kodeksu Prawa Kanonicznego Jana Pawła II," Roczniki Nauk Prawnych 1-2 (1991-1992): 17-28. 
Currently, the most common model of baptism is infant baptism, with the first Holy Communion, i.e., full participation in the Eucharist, taking place between the ages of 7 and 9, and the confirmation of the sacrament between 14 and 15 years or even later. In the context of baptism, it is worth mentioning the principle of the unity of the sacraments of Christian initiation, which is reflected in the law of the Church (c. $842 \S 2$ ). It may be surprising that the administration of the baptism in Eastern and Western traditions is different. In the East, time unity was preserved in the liturgical celebration of the three sacraments of Christian initiation, emphasizing the unity of the work of the Holy Spirit and the full integration of the child into the sacramental life of the Church. The same practice also applies in the Latin Church, however, in relation to adults. In the case of children, confirmation is usually delayed. The temporal separation of these two sacraments has no doctrinal justification, it is rather accidental and involves pastoral practice. In addition, it is customary for baptisms who have not yet been confirmed to receive Holy Communion. This is to serve to better prepare the child for the sacraments through Christian education at various stages of maturity. The Council's recommendations, reminiscent of the theological unity and order of the sacraments of initiation: baptism, confirmation, the Eucharist, were never lifted.

The faithful, incorporated into the Church through baptism, thanks to the received mark, are destined to participate in Christian worship and are reborn as sons of God, and obliged to profess the faith, which they received from God through the Church, to other people. Baptism is a sacrament of this faith, through which people enlightened by the grace of the Holy Spirit give the answer to the Gospel. The Church considers it its basic and main task to inspire everyone, whether catechumens or parents of baptised children, as well as sponsors, to the true and active faith.

By receiving baptism, a legal bond is created regarding belonging to the rite and the Church sui iuris. The sacrament is administered according to the liturgical ceremony of this very Church, into which the person receiving the baptism will be incorporated according to the law Acquisition of membership in the Church sui iuris by a person who is not baptized when they are under 14 years of age is related to their parents' church affiliation, parents' intentions, and canonical regulations. Interestingly, the very place of baptism plays a smaller role than the above-mentioned criteria, although everyone should be baptized according to the liturgical rite of the church sui iuris, to 
which he acquires membership, in accordance with the law. The baptism celebration visibly expresses the entrance to one's own Church sui iuris.

\section{BIBLIOGRAPHY}

ADAMOwICZ, Leszek. Wprowadzenie do prawa o sakramentach świętych: wedlug Kodeksu Prawa Kanonicznego oraz kodeksu Kanonów Kościołów Wschodnich. Lublin: Polihymnia, 1999.

BARTNIK, Czesław S. Dogmatyka katolicka. Vol. 2. Lublin: Wydawnictwo KUL, 2013.

BiszKo, Tomasz. "Sakrament chrztu św. w świetle Katechizmu Kościoła Katolickiego.” Legnickie Studia Teologiczno-Historyczne 14 (2009): 45-59.

Blanco, María, "Coment. sub can. 868." In MarzoA, MiRAs, and RodríguEZ-OcaÑA, Comentario Exegético al Código de Derecho Canónico, 3:487-89.

Catechism of the Catholic Church. Chicago: Loyola University Press, 1994.

Codex Iuris Canonici auctoritate Ioannis Pauli PP. II promulgatus, January 25, 1983: AAS 75 (1983), pars II, $1-317$.

Codex Iuris Canonici auctoritate Pii X Pontificis Maximi iussu digestus Benedicti. Papae XV auctoritate promulgatus, May 27, 1917: AAS 9 (1917), pars. II, 1-593.

CONGRegation for the Doctrine of the FAith. Instruction on Infant Baptism Pastoralis actio, October 20, 1980: AAS 72 (1980), 1137-56. https://www.vatican.va/roman_curia/congregations/ cfaith/documents/rc_con_cfaith_doc_19801020_pastoralis_actio_en.html.

GóRALSKI, Wojciech. "Wymiar ekumeniczny Kodeksu Prawa Kanonicznego Jana Pawła II.” Roczniki Nauk Prawnych 1-2 (1991-1992): 17-28.

International Theological Commission. The Hope of Salvation for Infants Who Die without Being Baptised. London: Catholic Truth Society, 2007. Also available on http://www.vatican.va/ roman_curia/congregations/cfaith/cti_documents/rc_con_cfaith_doc_20070419_un-baptisedinfants_en.html.

KAMIŃSKI, Rafał. "Wychowanie dzieci w małżeństwach mieszanych." In Chrzest i małżeństwo: harmonizacja ustawodawstwa, edited by Henryk Stawniak and Rafał Kamiński, 109-43.Warsaw: Scriptum, 2018.

KrzYwDA, Józef. “Chrzest.” In Komentarz do Kodeksu prawa kanonicznego. Vol. 3/2, Ksiega IV. Uświęcajace zadanie Kościoła, edited by Wojciech Góralski, Edward Górecki, Józef Krukowski, Józef Krzywda, Piotr Majer, and Bronisław Zubert, 35-65. Poznań: Pallottinum, 2011.

MarzoA, Ángel, Jorge Miras, and Rafael RodríGuEZ-OCAÑA, eds. Comentario Exegético al Código de Derecho Canónico. 4 vols. Pamplona: EUNSA, 1996.

MiкOŁAJCzUK, Krzysztof. Realizacja zasady jedności sakramentów wtajemniczenia chrześcijańskiego w prawodawstwie Kościoła Katolickiego. Kielce: Jedność, 2006.

MÜLLER, Gerhard L. Dogmatyka katolicka. Kraków: WAM, 2015.

NADOLSKI, Bogusław. Leksykon liturgii. Poznań: Pallottinum, 2006.

Pawluk, Tadeusz. Prawo kanoniczne wedtug Kodeksu Jana Pawła II. Vol. 1, Zagadnienia wstepne i normy ogólne. Olsztyn: Warmińskie Wydawnictwo Diecezjalne, 2015.

PAwluK, Tadeusz. Prawo kanoniczne wedlug Kodeksu Jana Pawła II. Vol. 2, Lud Boży jego nauczanie i uświęcanie. Olsztyn: Warmińskie Wydawnictwo Diecezjalne, 2010. 
Pontifical Council for Promoting Christian Unity. Directoire pour l'application des principes et des normes sur l'oecuménisme, March 25, 1993: AAS 85 (1993), 1039-119.

RINCÓN-PÉREZ, Tomás. "Disciplina canónica del Culto Divino.” In Manual de derecho canónico, obra a cargo del Instituto Martín de Azpilcueta, 405-548. Pamplona: EUNSA, 1988.

RinCón-PÉREZ, Tomás. La liturgia e i sacramenti nel diritto della Chiesa. Rome: EDUSC, 2014.

Rite of Baptism for Children, Washington, D.C.: United States Catholic Conference, 1969.

Vatican Council II. Dogmatic Constitution on the Church Lumen gentium, November 21, 1964 : $A A S 57$ (1965), 5-75. https://w2.vatican.va/archive/hist_councils/ii_vatican_council/documents/ vat-ii_const_19641121_lumen-gentium_en.html.

Vatican COUNCIL II. Declaration on Religious Freedom Dignitatis humanae, December 7, 1965: $A A S 58$ (1966), 929-46. http://www.vatican.va/archive/hist_councils/ii_vatican_council/ documents/vat-ii decl 19651207 dignitatis-humanae en.html.

SyCZEWSKI, Tadeusz. "Sakrament Chrztu Świętego.” Studia Teologiczne-Białystok-Drohiczyn-Lomża 15 (1997): $155-76$

\section{TEOLOGICZNO-KANONICZNE ASPEKTY MISTAGOGII CHRZCIELNEJ DLA OSÓB PONIŻEJ 14. ROKU ŻYCIA}

\section{Streszczenie}

Przedmiotem niniejszego artkułu jest ukazanie teologicznych podstaw udzielania sakramentu chrztu dzieciom oraz małoletnim, którzy nie ukończyli 14. roku życia, stanu prawnego, a także wynikających z niego implikacji duszpasterskich oraz administracyjnych. Konsekwencją chrztu jest uświęcające i usprawiedliwiające włączenie do ludu Bożego Nowego Przymierza. Nie może on zostać odwołany, a jego charakter sakramentalny jest nieusuwalny. Człowiek odrodzony wodą chrzcielną zostaje uwolniony od winy Adama i obdarzony siłą pokonywania zła. Autor odnosi się do tezy, jakoby chrzest dzieci naruszał ich wolność religijną. W artykule stwierdza się, że nie istnieje coś takiego jak „czysta wolność ludzka”, niezależna od jakiegokolwiek wpływu. Rodzice troszczą się o dobro dzieci i o to, co jest konieczne do życia. Dotyczy to także życia religijnego. Brak troski o ten aspekt byłby w rzeczywistości życzeniem zła poprzez pozbawienie istotnego dobra. Autor opisuje konsekwencje wynikające z sakramentu chrztu, poprzez który tworzy się węzeł prawny w konkretnym Kościele sui iuris.

Słowa kluczowe: chrzest; dziecko; nieletni; Kościół; wolność religijna; prawo. 